\title{
UTFORDRINGER VED PRIMA VISTA TOLKING I ASYLINTERVJUER
}

Tatjana Radanović Felberg

Høgskolen i Oslo og Akershus

Tatjana-radanovic.felberg@hioa.no

\section{Keywords:}

sight translation

asylum interviews

Norwegian Directorate of Immigration

interpreter-mediated dialogues

public sector interpreters 


\begin{abstract}
Every year the Norwegian Directorate of Immigration (UDI) conducts approximately 10,000 interpreter-mediated asylum interviews in Norway. Each asylum interview ends with the interpreter providing a sight translation of the draft interview report (an oral translation of the text) to the asylum seeker. The UDI wished to find out why some interpreters took so much more time than others for sight translation. In response, Oslo and Akershus University College of Applied Sciences initiated a pilot project. The project's working hypothesis was that slow sight translation was due mainly to a combination of three factors: interpreters' poor reading skills; interpreters' poor interpreting techniques; and/or interpreters' unfamiliarity with the appropriate genre/style. A more complex picture emerged, however, from an analysis of 13 asylum interviews; group work involving 108 UDI interpreters; and discussions with UDI specialists. An asylum report is the joint product of all the participants in an asylum interview, who are typically the asylum seeker, the interviewer and the interpreter. The pilot study showed that each participant could contribute in various ways to slowing the speed of sight translation. Contributing factors identified that were unrelated to the interpreter included the interviewer's competence in interview techniques; the interviewer's competence in creating a written record of speech; the asylum seeker's narrative ability; and the asylum seeker's ability to correct mistakes in the draft report. All these factors may have just as much impact on the speed of sight translation as the interpreter's competence. In addition, the physical strain caused by the length of asylum interviews (six hours plus) and the emotional stress potentially caused by such institutional interviews may affect the communicative abilities of all participants. As sight translation in the public sector is an under-researched area, the article starts with a discussion of terminology and an explanation of the UDI context. It then presents a possible explanation for slowness of sight translation and concludes that there is a need for more research into the various factors relevant to sight translation in the public sector and that there is a need to provide systematic training for both interpreters and interpreter users.
\end{abstract}




\section{Innledning}

Utlendingsdirektoratet (UDI) gjennomfører opp til 10000 intervjuer i søknader om beskyttelse (asylintervjuer) ${ }^{1}$ per år i Norge. Kommunikasjon mellom saksbehandleren som intervjuer og asylsøkeren i asylintervjuene foregår via tolk. Som regel skjer tolkingen konsekutivt, dvs. at hver replikk blir tolket umiddelbart etter at taleren er ferdig med å snakke. Asylintervjuet munner ut i en rapport på norsk, og det er intervjueren som skriver rapportene. På slutten av hvert intervju oversetter tolken intervjurapporten muntlig for asylsøkeren, fra skriftlig norsk til det aktuelle språket. Asylsøkeren godkjenner rapporten ved å signere på alle rapportens sider. Denne metoden, å oversette muntlig fra en skriftlig tekst, kalles prima vista tolking (PVT) i denne artikkelen.

PVT byr på flere utfordringer, både for tolken og tolkebrukerne (intervjuer og asylsøker). En av dem, sett fra UDIs ståsted ${ }^{2}$, handler om hastigheten på gjennomlesningen av rapportene, og UDI har observert at noen tolker bruker vesentlig mer tid enn gjennom-snittet tid til PVT av rapporter. Et grovt anslag viser at det er vanlig à bruke en time for PVT av 20 sider tekst. Samtidig hender det at gjennomlesing av en tekst på 15 sider varer i tre timer. Dette forlenger samlet tid til asylintervjuene betraktelig og fører til økt bruk av ressurser. I tråd med «større oppmerksomhet på effektivitet og produksjon» (Bollingmo, Skilbrei, \& Wessel, 2014: 78) ønsket UDI å finne ut om det er mulig å forbedre situasjonen.

Hovedproblemstillingen i denne artikkelen springer ut av denne praktiske problemstillingen og stiller spørsmålene: hva er årsaken til «langsom gjennomlesing» av rapporter i UDI, og hvordan kan man forbedre situasjonen?

For å forsøke å gi noen svar på disse spørsmålene ble det opprettet et pilotprosjekt ved Høgskolen i Oslo og Akershus (HiOA). ${ }^{3}$ Pilotprosjektet tok utgangspunkt i følgende arbeidshypotese: tolkens kunnskaper og ferdigheter påvirker lengden av PVT. Hensikten med prosjektet var 1) å kartlegge årsaker til «langsom gjennomlesing» av asylrapporter, 2) komme med forslag til målrettet opplæringsprogram ${ }^{4}$ og 3 ) generere eventuelle forskningsspørsmål som utforsker fenomenet videre. Denne artikkelen fokuserer på første del av pilotprosjektet - kartlegging av utfordringer ved PVT i asylintervjuer - og beskriver i tillegg noen av hovedfunnene i prosjektet.

PVT er en sammensatt oppgave som krever at tolken har gode tospråklige kunnskaper, bakgrunnskunnskap, gode leseferdigheter og evne til å tenke fremover. I tillegg må han eller hun ha/kunne oppmerksomhetsdeling, selvkontroll og presisjon (se bl.a. Sampaio, 2007; Weber, 1990). Forskningen om problemstillinger knyttet til PVT har nylig fătt større oppmerksomhet. Imidlertid er PVT i offentlig sektor lite beskrevet i litteraturen, og denne artikkelen er ment som et bidrag til å belyse PVT i en slik ramme.

I artikkelen beskrives fenomenet prima vista først generelt og så PVT av asylrapporter i UDI spesielt. PVT av asylrapporter er foreslått som sjette kategori $\mathrm{i}$ en av de allerede

1 Om terminologien brukt: følgende brukes om hverandre - søknad om beskyttelse $=$ asylintervju; saksbehandler som intervjuer $=$ intervjuer; intervjurapport $=$ rapport, asylsøker $=$ søker, prima vista tolking $=$ PVT; prima vista oversettelse $=$ PVO.

2 Opplysningene bygger på samtaler med enhetsleder Lena Grønland og seniorrådgiver Jasmina Gustavsen fra UDI. Begge jobber med UDIs kvalitetssystem for tolking og tolkefaglige spørsmål daglig. Jeg takker begge to for at de har bragt problemstillingen til HiOA og at de har deltatt aktivt i pilotprosjektet.

3 https://www.cristin.no/as/WebObjects/cristin.woa/wa/presentasjon

4 Forslaget til målrettet opplæringsprogram behandles ikke i denne artikkelen, det ble levert direkte til UDI. 
eksisterende kategoriseringene av PVT (Jimenez, 1999: 189-191). Deretter beskrives mulige årsaker til «langsom gjennomlesing» basert på litteraturgjennomgang, analyse av 13 asylrapporter og notatene fra gruppearbeid med 108 tolker som jobber i UDI. Resultatene viser at arbeidshypotesen var et godt utgangpunkt, men at den ikke dekker hele bildet. En vellykket PVT er nemlig avhengig av flere faktorer i tillegg til tolkens kunnskaper og ferdigheter. Både asylintervjueren og asylsøkeren er med på å bidra til, eller hemme, vellykket PVT. Prosjektet avdekket et behov for mer forskning på ulike aspekter ved PVT i offentlig sektor og et behov for systematisert opplæring av både tolker og tolkebrukere (intervjuere).

\section{Teoretisk og metodisk tilnærming}

Hypotesen om den stramme linen (tight rope hypothesis) (Gile, 2009: 182) sier at tolken mesteparten av tiden jobber i nærheten av sin fulle prosesseringskapasitet. Når vi vet at automatiserte kognitive prosesser tar mindre hjernekapasitet enn ikke-automatiserte prosesser (Gile 2009:158), blir konsekvensen av hypotesen at tolken bør automatisere så mange prosesser som mulig slik at hun/han făr frigjort prosesseringskapasiteten sin.

Ifølge Gile er det ulike typer innsats (effort) som tolken gjør for å utføre jobben sin, som for eksempel lytting, analyse, hukommelse, taleproduksjon osv. For å forklare hva som skjer når tolken tolker, har Gile utviklet en innsatsmodell for hver av disse metodene: simultan, konsekutiv, prima vista oversettelse ${ }^{5}$ og simultan tolking med tekst.

Modellene for konsekutiv og prima vista viser at tolking består av summen av ulike innsatser (se Tabell 1). De fleste av innsatsene er like for begge metodene: hukommelse, taleproduksjon og koordinering av de ulike innsatsene. Det som er forskjellig er lytting og analyse (Listening and Anaysis Effort) i konsekutiv tolking som blir til lesing (Reading Effort) i prima vista oversettelse. Jeg antar at analysedelen er innforstått i lesing. Hovedforskjellen mellom disse metodene blir deretter muntlig og skriftlig input. I løpet av pilotprosjektet ble det klart at mer fokus bør settes på tolkenes leseferdigheter.

Interpreting (consecutive) $=$ Listening and Analysis Effort + Note-taking + Short-term

Memory operations + Remembering + Note-reading + Speech Production Effort + Coordination

Konsekutiv tolking $=$ lytting + analyse + notater + kortidshukommelsesoperasjoner + huske + lesing av notater + taleproduksjon + koordinering

Sight translation $=$ Reading Effort + Memory Effort + Speech Production Effort + Coordination

Prima vista oversettelse $=\underline{\text { lesing }}+$ hukommelse + taleproduksjon + koordinering

Tabell 1: Modeller for konsekutiv og PVT, tilpasset etter Gile (2009: 175-176, 179).

5 Her brukes begrepet «prima vista oversettelse» ettersom Gile gjør det.

Tatjana R. Felberg, Utfordringer ved prima vista tolking i asylintervjuer 
Gile peker på at prima vista er noe lettere å utføre enn konsekutiv tolking fordi presset på korttidshukommelsen er noe mindre, i og med at kilden (her: teksten) er tilgjengelig for tolken hele tiden (Gile 2009:180-181). I tillegg kan tolken selv bestemme hastigheten for gjengivelsen. På den annen side fratar fravær av pauser og intonasjon tolken muligheten til à segmentere teksten. Derfor er det viktig at teksten er skrevet med riktig tegnsetting. Tolken må lese og forstå teksten samtidig og kan ikke gjøre en innsats for å forstå først, mener Gile. Spesielt når det gjelder språk som ikke har samme syntaktisk struktur, kan det kreve mye mer innsats og dermed mer tid for å utføre oppgaven (Lee, 2012: 695).

Det at teksten hele tiden er til stede, gjør imidlertid at interferensrisikoen mellom de to språkene blir større. Dette er en hypotese som er bekreftet av flere andre forskere (Agrifoglio 2004; Shreve, Lacruz, Angelone, 2010). I tillegg trekker forskerne fram følgende ferdigheter som tolkestudenter bør lære à beherske for à utføre PVT: rask tekstanalyse; rask oversettelse av informasjon fra ett til et annet språk; å unngå ord-for-ord-oversettelse og public speaking-teknikker (Lee, 2012: 695; Weber, 1990: 50).

Tolkingen foregår ikke $i$ et vakuum. Kommunikasjon generelt og kommunikasjon i offentlig sektor spesielt er et resultat av samhandling mellom alle deltakere i kommunikasjon (Wadensjö, 1998). Derfor er det viktig i fremtidige analyser å beskrive og analysere den institusjonelle konteksten: deltakernes relasjoner, maktforholdet, psyko-sosiale dimensjoner (deltakernes emosjonelle tilstand) og den fysiske dimisjonen (hvor og hvordan samtalen foregår).

\section{Metode og materiale}

UDI ønsket å finne ut noe om årsakene til den store forskjellen i hastighet i PVT hos ulike tolker. Beskrivelsen i denne artikkelen av hvordan PVT foregår i praksis i UDI, baserer seg på skriftlig materiale fra UDI (regelverk, UDIs interne meldinger og rundskriv) som er offentlig tilgjengelig, notater fra gruppearbeidet med UDI-tolker, notater fra møter med kontaktpersoner og innsyn i 13 asylrapporter fra 2012-2013 på fire språk (arabisk, tigrinja, engelsk og swahili). Asylrapportene ble valgt ut av kontaktpersoner i UDI. ${ }^{6}$ Kriteriene for utvelgelse var:

- intervjuene foregikk på språk hvor det allerede var identifisert problemer

- intervjuene skulle inkludere eksempler på gode gjennomlesninger

- forskerne kunne forstå de fleste aktuelle språkene

Rapportene ble analysert både kvantitativt (lengde og tolkingens hastighet) og kvalitativt. Materialet er begrenset, men burde være stort nok til at funnene kan illustrere generelle tendenser i materialet og danne grunnlag for utforming av forskningsspørsmål.

Som en del av pilotprosjektet ble det organisert en workshop om PVT for 108 av UDIs tolker i november 2013. Faginnholdet ble laget av HiOAs forskere i samarbeid med kontaktpersoner fra UDI.

I workshopen ble tolkene delt inn i grupper for å diskutere egne erfaringer med prima vista tolking (fordeler, ulemper og problemstillinger). Målet var at tolkene skulle belyse sin egen opplevelse av problemstillinger ved PVT, og gruppearbeidet ble senere presentert i plenum. Det skriftlige resultatet av gruppearbeidet ble levert til forskerne, og sammen med forskerens notater utgjør de ett av grunnlagene for analysen. I workshopens andre bolk

6 Kopi av rapportene ble levert til forskerne i anonymisert form og ble, etter analysen, returnert til UDI og makulert. 
gjennomgikk tolkene en leseferdighetstest. Testen viste så stor variasjon i leseferdigheter at konklusjonen var at dette aspektet bør vies mer oppmerksomhet i tolkeutdanning. ${ }^{7}$

\section{Definisjoner og kategorisering av prima vista}

Det at prima vista oversettelse blir kategorisert som en hybrid mellom oversettelse og tolking ettersom det handler om muntlig oversettelse av en nedskrevet tekst (se f.eks. Moser-Mercer 1991; Angelelli 1999), utfordrer den tradisjonelle forståelsen av tolking, mener (Jiménez Ivars, 1999). Dette gjenspeiles også i ikke-standardisert terminologi som brukes for fenomenet i litteraturen i ulike land. For eksempel brukes både sight translation, on-sight og at-sight translation i engelsk, a-vista translation i Italia og Polen (Bila-Wolonciej 2007: 30), mens man i Norge har brukt prima vista oversettelse.

Internt i UDI brukes begrepet «gjennomlesing» av rapporten. Dette er en mindre god betegnelse ettersom ordet skjuler det faktum at teksten blir oversatt fra ett språk til et annet. I mangel av noe bedre bruker jeg i denne artikkelen begrepet prima vista tolking ${ }^{8}$, ettersom det er enighet blant forskerne om at fenomenet ligger nærmere tolking enn oversettelse (Jiménez Ivars, 1999: 303). Begrunnelsen er at sammenlignet med tradisjonell oversettelse inneholder prima vista oversettelse umiddelbarhet som fremkommer gjennom muntlig gjengivelse i løpet av kort tid og under tidspress. I tillegg utføres PVT i norsk offentlig sektor i hovedsak av tolker og ikke av oversettere. Samtidig skjuler PVT-begrepet det faktum at tolken har vært med på å forme teksten ved å tolke fra det andre språket til norsk og deretter tilbake til norsk igjen. Prima vista, eller «sett for første gang», kan også være misvisende her, selv om det er første gang tolken ser teksten skriftlig på papir.

Prima vista oversettelse har blitt brukt som et pedagogisk redskap for å lære klassiske språk, eller som en innledning til opplæring i konsekutiv eller simultan tolking. Nyere eksperimentell forskning omhandler forskning av kognitive prosesser i prima vista ved bl.a. hjelp av eye tracking-metodologi (Chmiel \& Mazur, 2013; Shreve, Lacruz, \& Angelone, 2011). Imidlertid har det kommet en erkjennelse om at det er behov for utdanning og opplæring i prima vista som eget fagområde (Changmin, 2001; Ersozlu, 2005; Sampaio, 2007). En av grunnene til dette kan være at ikke bare konferansetolking er utgangspunkt for forskning om prima vista. Tolking i offentlig sektor innebærer endringer i oppdrag som tolker utfører i praksis, og dette har også bidratt til endringer i synet på prima vista. Det finnes allerede ulike typer håndbøker for tolker og tolkebrukere som forklarer det som er spesifikt med prima vista i ulike kontekster som for eksempel helsevesen og skole (Care, 2009; Stansfield, 2008).

I den gjennomgåtte litteraturen brukes det en del plass på å beskrive og kategorisere prima vista, ofte sammenlignet med andre typer oversettelse eller tolking (Agrifoglio, 2004; Jiménez Ivars, 1999; Lambert, 2004). Agrifoglio (2004) analyserer forskjeller mellom simultan, konsekutiv og prima vista oversettelse. Hun deler tolkeprosessen i to: mottak av informasjon og produksjon av tale. Hver av de to delene inneholder en del elementer som overlapper i de tre ulike tolkemetodene. Agrifoglio begynner med mottak av informasjon input - dvs. det som skal tolkes. I konsekutiv og simultan tolking er input muntlig, mens i prima vista er det skriftlig. Dette er en av de viktigste forskjellene mellom simultan/ konsekutiv og PVT. Videre er taleren til stede i konsekutiv og simultan tolking mens han/hun ikke er til stede i prima vista. Her er det e $\mathrm{n}$ forskjell mellom prima vista som Agrifoglio tar utgangspunkt i, og prima vista av rapporter i UDI. Agrifoglio tar utgangspunkt i

7 Resultatet og diskusjonen av testen blir publisert i en separat artikkel (Nilsen og Monsrud, forthcoming).

8 Emnet som omhandler prima vista tolking ved HiOA skal hete «Tolking fra skrift til tale».

Tatjana R. Felberg, Utfordringer ved prima vista tolking i asylintervjuer 
konferansetolking, mens jeg tar utgangspunkt i tolking i offentlig sektor. I dette tilfelle er asylsøkeren - hovedforfatteren - til stede i tillegg til to medforfattere - tolken og intervjueren. Søkeren har dessuten mulighet til å rette på rapporten på slutten av asylintervjuet.

Prosodi (tone, nøling, pauser) som hjelper tolken å segmentere teksten, er viktig både $\mathrm{i}$ simultan og konsekutiv tolking. I dokumentene som ligger til grunn for prima vista skal det finnes tegnsetting som erstatning for prosodi. Dette er viktig, ettersom mangelfull tegnsetting kan sammenlignes med mangelfull prosodi og kan lede til vanskeligheter $\mathrm{i}$ tolkingen. I simultan tolking brukes korttidshukommelse aktivt, i konsekutiv tolking brukes også langtidshukommelse og notater, mens i prima vista har man tilgang til teksten hele tiden. Oppmerksomhetsdeling i simultan tolking skjer mellom to parallelle lydkilder, i konsekutiv mellom audiosignaler og notater, og i prima vista mellom visuell input og muntlig output. Mottaket av input er sekvensiell i simultan- og konsekutiv tolking; det som skal tolkes høres bare én gang, mens prima vista har ikke-sekvensielt mottak, dvs. at tolken kan gå tilbake i teksten.

Mottaket er styrt av taleren i simultan og konsekutiv tolking mens det er styrt av tolken i prima vista. Imidlertid, i konsekutiv tolking i norsk offentlig sektor kan mottaket av konsekutiv tolking være styrt av tolken, og det er det ofte. Styringen, eller bedre sagt koordineringen av samtalen, skjer gjennom turtakingssignaler og spørsmål om gjentakelse eller forklaring av uklare ord/sekvenser. Denne muligheten til å sjekke informasjon er som oftest ikke til stede i tolking på konferanser.

Når det gjelder produksjon av tale, skjer taleproduksjon og tolking samtidig i simultan tolking, med kort forsinkelse i konsekutiv og med betydelig forsinkelse mellom tekstproduksjon og oversettelse i prima vista. I simultan tolking skjer en koordinering mellom lytting, hukommelse og produksjon, i konsekutiv tolking er det separasjon mellom lytting og produksjon og i prima vista er det koordinering av lesing og produksjon. Monitorering i simultan tolking skjer mens tolken lytter, i konsekutiv mens tolken noterer og i prima vista mens tolken leser. I simultan tolking er det progressiv tilgang til informasjon mens tolken tolker, som leder til høy risiko for interferens; i konsekutiv tolking skjer tilgang til informasjon før produksjon, noe som leder til lav risiko for interferens, mens det i prima vista er progressiv tilgang til informasjon som leder til ekstremt høy risiko for interferens. Produksjon i simultan tolking er styrt av taleren mens den i de to andre metodene er styrt av tolken. I simultan tolking er det dessuten som oftest mulig å få hjelp fra en kollega, ettersom det er vanlig at to-tre tolker jobber sammen, mens det i konsekutiv og prima vista som regel ikke er mulig å få hjelp av kollegaer.

\section{Kategorisering av prima vista oversettelse}

En oversikt over ulike kategorier av prima vista oversettelse finnes i Jimenez (1999: 189191).

1. «Ren» PVO - tolking av en skriftlig tekst som tolken ser for første gang. Tolken făr ingen tid til forberedelse.

2. Forberedt PVO - tolking av en skriftlig tekst med noe tid til forberedelse på forhånd.

3. Konsekutiv PVO - muntlig omformulering av en skriftlig tekst, del for del, etter at tolken har lest den ferdig.

4. PVO i konsekutiv tolking - ikke-lineær, muntlig reformulering av en skriftlig tekst, rett etter at den blir lest av en tolkebruker. Teksten erstatter notater, men tolken må passe på å ikke oversette det som ikke blir sagt av leseren. 
5. PVO i simultan tolking eller simultan tolking med tekst. Denne typen skiller seg fra vanlig PVO i det at PVO her ikke er kontrollert av tolken og at tolken ikke selv kan velge rytme/hastighet. Tolken må passe på utelatelser, tillegg og sidekommentarer, og paralingvistiske detaljer hos taleren som kan modifisere eller påvirke tolkingen.

Når det nå inkluderes UDIs kontekst - gjennomlesing av asylintervjuer - avtegnes det en sjette kategori til Jimenez' modell:

6. Tolking av en skriftlig tekst fra ett språk til et annet, som tolken har vært med på å utforme selv. Tekstens hovedforfatter (asylsøkeren) og medforfattere (intervjueren og tolken) er alle til stede, og det gis rom for rettelser i teksten.

Selv om det er en voksende forskningsinteresse for PVT med utgangspunkt i konferansetolking, er det fremdeles vanskelig å finne forskning som omhandler PVT i offentlig sektor generelt og tolking ved asylintervjuer spesielt. I offentlig sektor i Norge, skjer prima vista i ulike typer situasjoner med ulike kommunikasjonsdeltakere til stede slik at man må ta hensyn til en rekke ekstralingvistiske aspekter. I følgende avsnitt går vi mer i detalj på en konkret kontekst: PVT i UDI.

\section{Hva kjennetegner PVT i intervjuer om beskyttelse gjennom UDI?}

UDI er en statlig institusjon som har som hovedmål å sette i verk regjeringens innvandrings- og flyktningpolitikk. ${ }^{9}$ UDI behandler blant annet søknader om beskyttelse (asyl). Hvordan et intervju i søknader om beskyttelse foregår, er beskrevet i UDIs interne melding (IM 2013-011). ${ }^{10}$ Formålet med intervjuet er $\mathrm{i}$ henhold til meldingen å «innhente tilstrekkelig pålitelig informasjon til at UDI kan vurdere om søkeren har krav på beskyttelse eller kan gis opphold på humanitært grunnlag» (min uthevelse).

$\AA$ «innhente tilstrekkelig pålitelig informasjon» innebærer å innhente fakta som kan underbygge pålitelighet. En gjennomgang av rapportene tyder på at asylsøkere ofte er opptatt av å formidle sine egne følelser og hendelser som er særlig viktige for dem. De deler ikke nødvendigvis UDIs forståelse av hva slags fakta som er gode nok for å kvalifisere til beskyttelse. Det er blitt påpekt at asylintervjuet «er en sjanger det lønner seg for søkere à beherske» (Bollingmo et al., 2014: 24). Relasjonen mellom deltakerne i et asylintervju er asymmetrisk. Det er intervjueren som har kontroll, som stiller spørsmål og skriver ned rapporten. Samtidig har asylsøkeren mest kompetanse på sitt eget liv og sin egen historie. Det kan også hende at søkeren er intervjueren «overlegen» med hensyn til kunnskaper og ikke minst formuleringsevne på morsmålet. Siden intervjueren er den som forfatter teksten, vil denne asymmetrien utgjøre en risiko for at mening og nyanser hos søkeren ikke blir fanget opp.

UDI bruker strukturert intervjumetode for målrettede samtaler til å innhente informasjon fra søkeren. Metoden er inspirert av den dialogiske samtalemetoden; DCM (Langballe, Gamst, \& Jacobsen, 2010: 34; Rachlew, 2011). Dette er en intervjumetode som består av åtte faser: 1 . forberedelse, 2 . kontaktetablering, 3. innledende prosedyrer, 4 . introduksjon til tema, 5. fri fortelling, 6. temasondering, 7. avslutning og 8. evaluering. Tolkene som har tolkeutdanning făr informasjon om denne metoden i studiene, og i tillegg er den formidlet til tolkene som en del av den interne opplæringen i UDI. Det anses som meget viktig at alle kommunikasjonsdeltakere, inkludert tolken, er fortrolige med metoden og forstår hensikten med de ulike fasene i intervjuet.

9 www.udi.no

10 http://www.udiregelverk.no/no/rettskilder/udi-interne-meldinger/im-2013-011/im-2013-011v11/

Tatjana R. Felberg, Utfordringer ved prima vista tolking i asylintervjuer 
Forberedelsesfasen skjer før selve intervjuet og består av intervjuerens fysiske, mentale og saksrelaterte forberedelser. Kontaktetableringsfasen er den første fasen i selve intervjuet. Intervjueren presenterer seg selv, og tolken og sørger for «trygge og forutsigbare rammer for intervjuet». I den innledende prosedyren informerer intervjueren søkeren om rettigheter og plikter, formålet med samtalen og intervjuerens og tolkens ansvar og oppgaver. Måten dette skal gjøres på, er også beskrevet i den interne meldingen:

«Intervjueren skal legge vekt på å gi informasjon i et enkelt og tydelig språk, og på en slik måte at søkeren har mulighet til å forstå. Saksbehandleren skal tilrettelegge for at søkeren får god anledning til å stille spørsmål underveis og ved behov undersøke om søkeren har forstått.» IM2013-11: 3).

Etter introduksjonen lar intervjueren søkeren fortelle fritt om sin sak, og deretter følger temasonderingsfasen der intervjueren innhenter mer detaljert informasjon ved bruk av spesifikke spørsmål. Mens asylsøkeren forteller sin historie, skriver intervjueren rapporten. Sjangerskjema til rapporten ligger $i$ intervjuerens PC, og intervjueren fyller ut det som trengs. I avslutningsfasen skjer det som er forskningsobjektet for denne artikkelen, rapportgjennomlesing eller PVT av rapporten. Etter at intervjuet er ferdig, skriver asylintervjueren rapporten ut og gir utskriften til tolken, som så tolker rapporten fra norsk til det aktuelle språket. Målet med gjennomlesingen er at intervjueren skal kontrollere at all informasjon er med og at asylsøkeren skal ha mulighet til å korrigere eventuelle feil. Alt som er skrevet blir tolket, og hvis det er noen endringer, føyes de inn i rapporten.

Asylintervju er en type institusjonell samtale med flere kommunikasjonsdeltakere. Vanligvis er det tre personer til stede: intervjueren, asylsøkeren og tolken. I noen tilfeller kan andre være med, for eksempel verge ved intervju av enslige mindreårige, advokat, eller en tolk under opplæring. Rapporten blir på den måten et felles produkt av minst tre personer tolken, asylsøkeren og asylintervjueren.

Praksis i hva som skjer videre med rapporten har variert i UDI. I noen perioder har rapporten blitt sendt til en annen saksbehandler som skulle avgjøre saken, mens $\mathrm{i}$ andre perioder har intervjueren selv fattet vedtak som saksbehandler (Bollingmo et al., 2014: 68). Dette betyr at rapportens sentrale lesere kan være både en saksbehandler som ikke er til stede og asylsøkeren som er til stede. I noen tilfeller kan rapporten også bli lest av advokater, politiet eller Utlendingsnemnda.

Rapporten skal inneholde all informasjon «som er relevant for søknaden om beskyttelse», og i notatet Hvordan skrive asylintervjurapporten ${ }^{11}$ står det: «Søkerens svar skal også skrives ned, så nært søkerens egen måte å formulere seg på som mulig» (min uthevelse). Den uthevede formuleringen kan by på utfordringer både når asylsøkeren eller tolken har problemer med å uttrykke seg, og når intervjueren har problemer med å formulere historien skriftlig i rapporten. Noen intervjuere skriver ordrett ned det søkeren forteller (via tolken) mens andre redigerer og omformulerer (Bollingmo et al., 2014: 72).

Ingen steder i de notatene prosjektet har gjennomgått, er det nevnt at gjennomlesingen skjer ved tolking. Dette kan være problematisk hvis det underveis glemmes at rapporten er et produkt av flere medieringssprosesser. Den første medieringsprosessen er asylsøkerens utforming av historien, den andre er tolkens tolking av historien til norsk. Den tredje er intervjuerens omforming fra muntlig til skriftlig språk på papir, og den fjerde er PVT fra norsk til det andre språket. Intervjuerne er imidlertid klar over at tolking kan påvirke deres troverdighetsvurdering.

11 http://www.udiregelverk.no/no/rettskilder/udi-interne-meldinger/im-2013-011/im-2013-011v3/

Tatjana R. Felberg, Utfordringer ved prima vista tolking i asylintervjuer 
«På spørsmål om tolking gjør det vanskelig å gjøre en troverdighetsvurdering, svarer ni prosent ( $N$ 121) at det aldri er vanskelig, 69 prosent synes det er vanskelig av og til, mens seks prosent svarer «halve tiden», åtte prosent «ofte» og to prosent sier at det alltid er vanskelig.» (Bollingmo et al., 2014: 70-71)

Tolking i UDI er behandlet $i$ et separat rundskriv Bruk av tolk $i$ utlendingssaker ${ }^{12}$, og her nevnes prima vista under punkt 3.3 Grenser for tolkens ansvarsområde:

«I den grad tolken vurderes å ha tilstrekkelige kvalifikasjoner til dette, kan tolken gis i oppdrag å tolke fra skriftlig tekst (prima vista), å muntlig oversette datoer fra en kalender til en annen, og å skrive ned og transkribere navn fra et språk som benytter et annet alfabet enn det latinske til norsk.»

Ordlyden i rundskrivet viser at UDI erkjenner at det muligens finnes tolker som ikke har tilstrekkelige kvalifikasjoner til å tolke prima vista. Dette er forståelig, ettersom PVT ikke har blitt gitt som eget emne på tolkeutdanningen, en situasjon som nå er i ferd med å endres.

Når det gjelder de fysiske omgivelsene, foregår asylintervjuer på offentlige kontorer på ulike steder i Oslo og i Trondheim. Noen intervjuer foregår via videokonferanseutstyr slik at tolken for eksempel kan befinne seg på Østlandet mens asylintervjuet foregår i Trondheim. Ved bruk av fjerntolking kan PVT fra skjerm by på tilleggsproblemer for tolken. Tolken blir ekstra sliten i de tilfellene rapporten på mange sider må leses fra skjerm.

Ifølge rundskrivet er kontorene tilrettelagt for formålet. Det finnes bord med PC for intervjueren, stoler for tolken og asylsøkeren og evt. andre tilstedeværende. Det er lagt til rette for at intervjuet skal kunne foregå uten forstyrrelser (støy, at andre personer kommer inn osv.) Det tas regelmessige pauser.

Den fysiske rammen for asylintervjuet kan også påvirke kommunikasjon. Kommunikasjonsdeltakeres sitteposisjon, fysisk avstand mellom deltakere og mulighet for bevegelse, er elementer som enten kan hemme eller fremme kommunikasjonen. Disse multimodale elementene er ikke blitt analysert i pilotprosjektet ettersom det ikke finnes videoopptak av intervjuene, men tematikken bør inkluderes i fremtidig forskning.

\section{Beskrivelse og analyse av rapporter}

Beskrivelsen og analysen av asylrapportene i dette prosjektet er gjort for å utforske mulige utfordringer som rapporten i seg selv kan utgjøre for tolken. Med utgangpunkt i hypotesen om den stramme linen kan man formulere spørsmålet om det er noe i formen på rapporten som kan kreve ekstra innsats fra tolken og som dermed kommer på toppen av de andre innsatsene tolken skal gjøre. Kan dette «noe» automatiseres og dermed frigjøre mer kapasitet for tolken?

Siden antall gjennomgåtte intervjuer er lite, gir dette avsnittet kun en pekepinn om mulige problemstillinger som bør undersøkes videre med flere asylrapporter som materiale.

Alle rapportene følger et rapportskjema som består av fire hoveddeler: 1) personalopplysninger, 2) årsakene til søknaden om beskyttelse, 3) utfyllende informasjon og 4) andre opplysninger og merknader. Selv om asylrapportene har samme sjangerskjema i bunn, varierer de både kvantitativt (lengde og hastighet) og kvalitativt (innhold, struktur, sjanger og stil). Dette er som forventet ettersom rapportene forteller historiene til ulike mennesker under ulike omstendigheter. Når det gjelder ulik bruk av malen, ble funnet fra

12 RS 2011-039 http://www.udiregelverk.no/no/rettskilder/udi-rundskriv/rs-2011-039/

Tatjana R. Felberg, Utfordringer ved prima vista tolking i asylintervjuer 
pilotprosjektet bekreftet av en større undersøkelse hvor 50 prosent av intervjuerne oppgir at de alltid bruker mal mens 27 prosent benytter mal ofte. De resterende bruker mal halve tiden, av og til eller aldri (Bollingmo et al., 2014: 44-45).

Det er observert variasjon både i lengde på asylintervjuene og rapportgjennomlesningene. Et gjennomsnitts asylintervju varer i seks og en halv time. ${ }^{13}$ Som regel blir asylintervjuet ferdig i løpet av en dag, men i noen tilfeller forlenges det med en ekstra dag. I det analyserte utvalget er variasjonen på asylintervjulengde fra i underkant av tre timer og opp til ni timer (se Tabell 2).

Rapportene lagres som pdf-filer. Lengden på de gjennomgåtte rapportene varierer fra åtte til 20 sider.

Når det gjelder antall ord, varierer dette fra 1165 til 6948 ord per rapport. ${ }^{14}$ Gjennomlesningstiden (PVT) varierer fra 16 til 105 minutter. Når det gjelder antall minutter per side varierer gjennomlesningene fra 1,8 til 7,2 minutter. En grov beregning ${ }^{15}$ på gjennomsnitts antall ord per minutt viser at resultatet varierer fra 71 ord per minutt til 132 ord per minutt. Dette bekrefter asylintervjuerens opplevelse av at noen gjennomlesinger går mye fortere enn andre.

\begin{tabular}{|l|l|l|l|l|l|l|}
\hline & Språk & $\begin{array}{l}\text { Antall } \\
\text { sider } \\
\text { (pdf fra } \\
\text { UDI) }\end{array}$ & $\begin{array}{l}\text { Antall } \\
\text { ord }\end{array}$ & $\begin{array}{l}\text { Antall } \\
\text { min per } \\
\text { side }\end{array}$ & $\begin{array}{l}\text { Antall ord } \\
\text { per min. }\end{array}$ & $\begin{array}{l}\text { A)Intervjuvarighet inkl. B } \\
\text { B) Gjennomlesning }\end{array}$ \\
\hline 1 & Afr. engelsk & 16 & 3726 & 1,8 & 124,2 & $\begin{array}{l}\text { A) 09:10-14:10 } \\
\text { B) } 30 \text { min }\end{array}$ \\
\hline 2 & Afr. engelsk & 15 & 4627 & 2,3 & 132,2 & $\begin{array}{l}\text { A) 09:00-15:00 } \\
\text { B) } 35 \text { min }\end{array}$ \\
\hline 3 & $\begin{array}{l}\text { Afr. } \\
\text { engelsk } \\
\text { To tolker, to }\end{array}$ & 20 & 6948 & 4 & 86,85 & $\begin{array}{l}\text { A) 09:20-16:15 } \\
\text { A) 09:00-10:50 } \\
\text { B) } 1 \text { time } 30 \text { min (inkl. } 10 \text { min pause) }\end{array}$ \\
\hline 4 & swahili & 20 & 6385 & 4,5 & 70,9 & $\begin{array}{l}\text { A) 09:20-15:57 } \\
\text { B) } 1 \text { time } 30 \text { min }\end{array}$ \\
\hline 5 & arabisk & 16 & 6166 & 3,7 & 102,7 & $\begin{array}{l}\text { A) 09:15-15:45 } \\
\text { B) } 1 \text { time }\end{array}$ \\
\hline 6 & arabisk & 7 & 1165 & 2,2 & 72,8 & $\begin{array}{l}\text { A) } 10: 00-13: 00 \\
\text { B) } 16 \text { minutter }\end{array}$ \\
\hline 7 & arabisk & 15 & 3831 & 3 & 85,1 & $\begin{array}{l}\text { A) } 10: 00-14: 00 \\
\text { B) } 45 \text { min }\end{array}$ \\
\hline 8 & arabisk & 8 & I/T & 4,3 & $\begin{array}{l}\text { I/T (ikke } \\
\text { tilgjengelig) }\end{array}$ & $\begin{array}{l}\text { A) 09:00-11:55 } \\
\text { B) } 35 \text { min }\end{array}$ \\
\hline 9 & tigrinja & 12 & I/T & 2,5 & I/T & $\begin{array}{l}\text { A) 09:00-13:00 } \\
\text { B) } 30 \text { minutter }\end{array}$ \\
\hline 10 & tigrinja & 14 & I/T & 5,3 & I/T & $\begin{array}{l}\text { A) 09:00-15:00 } \\
\text { B) } 1 \text { time } 15 \text { min }\end{array}$ \\
\hline 11 & tigrinja & 19 & I/T & 5,5 & I/T & $\begin{array}{l}\text { A) 09:20-15:20 } \\
\text { B) } 1 \text { time } 45 \text { min }\end{array}$ \\
\hline 12 & tigrinja & 11 & I/T & 7,2 & $\begin{array}{l}\text { A) 09:00-15:55 } \\
\text { B) } 1 \text { time } 30 \text { min (inkl.10 min pause) }\end{array}$ \\
\hline 13 & tigrinja & 10 & I/T & 5 & $\begin{array}{l}\text { A) 09:10-16:00 } \\
\text { B) } 50 \text { min }\end{array}$ \\
\hline
\end{tabular}

Tabell 2: Kvantitativ oversikt over intervjuene

13 Kilde - UDI.

14 Antall ord er regnet med ordtellingsfunksjon i Word for de rapportene som forelå elektronisk.

Elektronisk versjon av rapporten var ikke tilgjengelig for rapporter fra nr 8-13., dermed ingen resultat.

15 Her har jeg brukt en forenklet metode for å regne ut gjennomsnittlig antall ord per minutt. Jeg delte antall ord i rapporten (norske ord) med tiden brukt for gjennomlesning. Dette tallet sier noe om opplevd hastighet, sett fra intervjueren sin side. Denne metoden tar ikke hensyn til antall intervensjoner (rettelser, bekreftelser osv.) fra asylsøkeren og hvordan rapporter er skrevet. 
Når det gjelder hvor raskt tolken jobber, har Moser-Mercer kommet til resultatet på 60 ord per minutt for urutinerte og 115 per minutt for profesjonelle tolker (referert i Lambert 2004: 299), mens Lee fikk resultatet på gjennomsnitt 70.63 ord per minutt for studenter og 93.97 ord per minutt for profesjonelle tolker, mellom koreansk og engelsk (Lee 2012). Denne sammenligningen er interessant fordi det viser en felles tendens - de som har mer kompetanse skårer bedre - selv om de gjengitte dataene tar utgangpunkt i eksperimenter, mens vi ser på eksempler fra praksis. Dessuten er det vanskelig å måle hastighet i UDIs kontekst. Hva skal man måle- antall sider per time? Antall ord per minutt i kildeteksten? Antall ord i gjengivelsen? Hva er gjennomsnittshastigheten, per minutt av ren tale uten pauser, selv-rettelser osv., eller per minutt intervjutid?

Et viktig poeng når vi diskuterer hastighet i PVT, er forholdet mellom hastighet og kvalitet. Påvirker høyere hastighet kvaliteten negativt? ${ }^{16}$

Det er en del variasjon i hvordan rapportene er skrevet, og som tidligere nevnt er dette forståelig fordi rapportene skal gjenspeile søkerens historie og språkføring «så nært som mulig originalen».

Det er forskjell mellom den formelle stilen som UDI gjerne bruker i sine skjemaer (for eksempel under avsnittet «andre opplysninger og merknader») og den uformelle stilen som søkeren (mediert gjennom tolken og intervjueren) oftest har. Den formelle stilen brukes i institusjonelle sammenhenger og knyttes til skriftlig språk, mens den uformelle stilen brukes i privatsfæren og knyttes som oftest til muntlig språk. En blanding av disse resulterer i blanding av stiler og hybridstiler som kan påvirke tolkens tolking. Et godt eksempel på den formelle, skriftlige stilen (som prima vista tolkes til asylsøkeren) er denne formuleringen:

«Søkeren bekrefter å ha fătt informasjon om at: det er viktig å forklare seg nøyaktig og sannferdig, og at om søkeren bevisst oppgir uriktige opplysninger kan det få konsekvenser for hvordan søknaden blir behandlet.»

I kontrast til dette står den muntlige, fortellende stilen:

«De kommer mot meg og begynner å slå meg, og jeg sier: nei, nei, la meg være, jeg har ikke gjort noe feil. Og da sier jeg til dem at de bør la meg være i fred, at jeg er en stakkars person, en vanlig person.»

Her er det viktig å nevne at det ikke finnes mye tekst av den første typen, men at det allikevel er viktig at tolken behersker både den formelle og den uformelle stilen.

Det er også mulig å observere variasjon i hvordan ulike intervjuere leder asylintervjuer, for eksempel i hvordan de stiller oppfølgingsspørsmål etter frifortellingsdelen. Inntrykket som forskeren har fătt, at noen spørsmål kan virke mer konfronterende enn andre og at noen formuleringer kan få søkeren til å lukke seg, bekreftes også i rapporten (Bollingmo et al., 2014: 89), som konkluderer med at det er «variasjoner i hvordan saksbehandlere vektlegger og nærmer seg de ulike delene i asylsøkerprosessen». Dette inkluderer både delen med fri fortelling og temasonderingsdelen.

«Noen saksbehandlere tar tilsynelatende dette [fri fortelling] så ordrett at de knapt stiller spørsmål underveis, og man ender opp med lite informasjon som er relevant for à belyse søkers behov for beskyttelse. Andre stiller fokuserte og til dels konfronterende spørsmål fra starten av intervjuet.» (Bollingmo et al., 2014: 92)

16 Dette spørsmålet ble ikke utforsket i pilotprosjektet, men er et viktig tema for fremtidig forskning. 
Verbale uttrykksformer (åpne vs. lukkede spørsmål, ikke-ledende versus ledende spørsmål, aktiv versus passiv lytting osv.) er et stort tema, og retorikkens funksjon i samtale bør stå sentralt i videre forskning.

Som tidligere nevnt er tegnsettingen viktig for PVT fordi den erstatter prosodiske hjelpemidler (jf. Gile 2009). Ingen av de analyserte rapportene inneholder anførselstegn, men flere rapporter bruker kolon for å antyde at det kommer direkte tale. Systematisk bruk av anførselstegn ved direkte tale kan være med på å heve presisjonsnivået i rapportene.

Går vi tilbake til spørsmålet om hva som påvirker hastigheten i PVT, ser vi at man vanligvis først og fremst tenker at svaret ligger i tolkens ferdigheter. Hvis en tolk er flink teknisk, går gjennomlesingen fortere. Og sant nok var det i det analyserte materialet mulig å observere variasjon mellom tolker når det gjelder kunnskaper i det andre språket. Imidlertid er det andre variabler som påvirker hastigheten, som for eksempel mellom hvilke språk oversettelsen foregår på, hvordan rapporten er skrevet og intervensjoner fra asylsøkeren. Hvis oversettelsen foregår mellom språk som står hverandre forholdsvis nær, som for eksempel norsk og engelsk, ser det ut som om det går bedre enn når oversettelsen foregår mellom språk som er fjernere fra hverandre, som for eksempel norsk og swahili.

Videre er det en del variasjon i hvordan rapportene er skrevet. Hvis rapportene er skrevet i et klart språk, uten for mange innskutte leddsetninger og med riktig tegnsetting, går gjennomlesningen bedre.

Intervensjoner fra asylsøkeren eller intervjueren kan forlenge intervjuet. I materialet finnes det et eksempel på intervensjon hvor intervjueren forslår en pause: «Har tolken lyst på en pause?» og der tolken avviser tilbudet og fortsetter å tolke.

Asylsøkeren har anledning til å rette på ting han eller hun mener ikke er riktig i rapporten, og denne muligheten brukes av noen. Det var noen få rettelser $\mathrm{i}$ de gjennomgåtte rapportene, og de er merket i rapporten som rettelser. Rettelsene er av denne typen:

«Etter at $\mathrm{N}$ døde, dro jeg til $X$ via $Y$, altså ikke til $Y$ via $X . »$

Avsnittet startet med et mål om å «utforske mulige utfordringer som rapporten i seg selv kan utgjøre for tolken». Det ble observert følgende mulige utfordringer: manglende tegnsetting i rapporter, blanding av ulike stiler og ulike måter rapportene er skrevet på. Det à tolke uten å kjenne intervjumetoden som er brukt $i$ intervjuer er også en potensiell utfordring for tolker.

Analysen avtegner et komplekst bilde: vellykket gjennomlesing (korrekt gjengivelse og akseptabel hastighet) er avhengig av flere faktorer hos minst tre aktører: tolken, asylsøkeren og asylintervjueren (og noen ganger verge eller advokat). Denne konklusjonen ble bekreftet og utdypet i møte med tolker som jobber for UDI, og beskrives i neste avsnitt.

\section{Tolkenes stemmer}

Følgende er en oppsummering av tolkenes tilbakemeldinger basert på resultatet av gruppearbeidet til de 108 UDI-tolkene som var med på workshopen om PVT i november 2013. Tolkene ble delt i ti grupper og skulle svare på spørsmål om utfordringer og fordeler med PVT. Svarene de ga, tegner et sammensatt bilde av utfordringene ved PVT, både for tolkene selv, intervjuerne og asylsøkerne.

Svarene tolkene ga kan deles i tre grupper: utfordringer relatert til tolkens kunnskaper og ferdigheter, etiske problemstillinger og fysisk/mentalt stress. For at tolken skal mestre a tolke prima vista, kreves både bred generell kunnskap, kjennskap til sjanger og terminologi i konteksten og god tolketeknikk, mente tolkene. Videre bør tolken ha gode leseferdigheter. Noen mente at det var en fordel å ha teksten foran seg hele tiden. Det gjorde jobben lettere 
ettersom teksten avlastet hukommelsen. Andre opplevde det som en utfordring à ha teksten foran seg - de mente det var vanskeligere å huske det riktige ordet på det andre språket når man så på ord skrevet på norsk.

En annen situasjon som tolkene fremhevet, er den som oppstår når tolken ikke bruker akkurat samme ord i «back translation» som ble brukt av asylsøkeren. Asylsøkeren kan i disse tilfellene miste tillit til tolken. Dette kan skje når en tolk tolker rapporten etter at en annen tolk har tolket intervjuet først, eller i tilfeller der intervjuet varer i to dager. I slike situasjoner kan det oppstå behov for avklaringer som tar lang tid og påvirker hastigheten på gjennomlesingen av rapporten.

De fleste tolkene uttrykte bekymring rundt noen etiske problemstillinger som de selv opplever ved PVT. Hva skjer for eksempel når tolken har tolket noe riktig, men intervjueren har misforstått og skrevet feil i rapporten? Bør tolken rette dette? En annen etisk problemstilling er når tolken oppdager at ord og utsagn er gjengitt feil i rapporten, men uten at noen av partene reagerer. Bør tolken gjøre dem oppmerksom på dette? Et annet eksempel er en situasjon hvor tolken forstår at den formelle stilen fra intervjueren ikke blir forstått av søkeren. Bør tolken forenkle språket? Disse problemstillingene oppstår ikke bare i PVT, men det er interessant at tolkene fremhevet dem særlig i PVT-sammenhengen. Forskeren lurer på om det er fordi man har et skriftlig «bevis» på det som tolkes, at problematikken oppleves som så viktig? Eller er det fordi tolkene mangler fora for diskusjoner om etiske dilemmaer og gruppearbeidet var en mulighet de utnyttet?

En annen utfordring som er til stede $\mathrm{i}$ all tolking, er det fysiske, mentale og psykologiske stresset, og maktforholdet i samtalen. Tolkene nevnte at det er meget slitsomt å tolke $\mathrm{i}$ fem-seks timer først, for så å tolke prima vista på slutten av dagen. Tolkene merker at konsentrasjonen blir påvirket, spesielt hvis de tolker i emosjonelt vanskelige saker.

Flere tolker nevnte at de har tolket for asylsøkere som ser ut til ikke å vise interesse for sin egen sak. Noen asylsøkere sovner til og med under gjennomlesingen, mens andre ikke reagerer på opplagte feil og ikke benytter sjansen til å korrigere. Begrenset vokabular og manglende evne til å utrykke seg hos noen asylsøkere, er en annen utfordring for tolkene. Som oftest erkjenner tolkene at disse søkerne har lite skolegang og lavt utdanningsnivå. Her oppstår igjen det etiske dilemmaet - skal de forenkle språket når de tolker fra norsk, og skal de «forbedre» språket når de tolker til norsk, eller skal de følge Retningslinjer for god tolkeskikk ${ }^{17}$

Tolkene mente også å ha observert at fysisk, mentalt og psykologisk stress og maktforholdet i samtalen også påvirker asylsøkere. Man kan derfor spørre om det er fysisk utmattelse, mangelfull forståelse for viktigheten av asylintervjuet eller en kombinasjon av disse faktorene som gjør at noen asylsøkere ikke følger med i rapportgjennomlesningen. Dette er et spørsmål som bare asylsøkerne selv kan svare på.

Tolkene bemerker at noen rapporter er preget av ujevnt språk og skrivefeil. Dette kan gjøre det vanskelig for tolken å forstå det nøyaktige innholdet i teksten som skal tolkes prima vista. Noen tolker la merke til at det er stor variasjon i hvordan intervjueren ${ }^{18}$ administrerer og leder intervjuet og hvordan ulike intervjuere stiller oppfølgingsspørsmål. Forventninger til tolken og hvordan intervjueren takler rettelser kan også variere hos de ulike intervjuerne. Noen intervjuere forventer, ifølge noen tolker, at tolken skal gjøre mer enn bare å tolke.

17 http://www.tolkeportalen.no/For-tolker/Tolkens-yrkesetikk/

18 I første fase av pilotprosjektet ble ikke intervjuerens side inkludert. En undersøkelse blant intervjuere er planlagt i neste fase av prosjektet. 
Asylintervjuet sett fra intervjuerens side er ikke inkludert i dette prosjektet, men det er rimelig å anta at de same faktorene som påvirker tolken og asylsøkeren - fysisk, mentalt og psykologisk stress og maktforholdet i samtalen - også påvirker intervjueren.

\section{Konklusjon}

Fra UDIs ståsted er tidsforbruket den største utfordringen med PVT, og direktoratet har interesse av å avdekke årsaker til at noen asylintervjuer munner ut i «langsom gjennomlesing». Dette leder forskeren til to spørsmål til fremtidig forskning: 1) Hva er rask/normal/langsom PVT på ulike språk, og 2) Hvordan er forholdet mellom hastighet og kvalitet på tolkingen?

Analysen av et utvalg rapporter og gruppearbeid med tolker som jobber for UDI, avtegnet et sammensatt og nyansert bilde av mulige årsaker til «langsom gjennomlesing». I motsetning til pilotprosjektets foreløpige hypotese, hvor bare tolkens ferdigheter var under lupen, ble det klart at alle deltakerne i kommunikasjon kan påvirke lengden på rapportgjennomlesningen.

PVT er en kompleks oppgave som krever at tolken har gode kognitive og lingvistiske ferdigheter inkludert leseferdigheter, og er fortrolig med å skifte fra skriftlig til muntlig språk. Tolken må kunne analysere og presentere tekst og ha god stemmebruk med klar uttale og rytme. Det kreves i tillegg fysisk og mental utholdenhet, evne til å mestre stress og gode konsentrasjonsevner.

Årsakene til avvik kan ligge i hvilken som helst av disse ferdighetene til tolken. I løpet av pilotprosjektet ble leseferdigheter til UDI-tolkene testet, og resultatet tyder på behov for bedre og mer systematisk opplæring.

Årsakene til «langsom gjennomlesing» kan også ligge hos de andre kommunikasjonsdeltakerne, og i selve konteksten for asylintervjuet. Intervjuernes kompetanse i intervjuledelse er meget viktig for at et asylintervju blir vellykket. Når det gjelder PVT, er det av vital betydning å kunne omformulere fra muntlig til skriftlig språk og utforme en tekst som egner seg til à leses høyt i løpet av veldig kort tid.

Asylsøkere på sin side påvirker lengden på intervjuet, både fordi det kan være stor variasjon i hvor mye som er å fortelle, og fordi noen forteller godt og flytende, mens man må «trekke» ordene ut av andre. Det ble også bemerket av tolkene at asylsøkerens interesse for sin egen historie påvirker intervjuet. Til slutt ser det ut som om lengden på asylintervjuer påvirker den fysiske tilstanden til alle kommunikasjonsdeltakere. Jo lengre intervjuet varer, jo større sjanse for at alle deltakere blir slitne og mister konsentrasjon. Her mangler det mer forskning på hvilke faktorer som spiller inn når asylintervjuet trekker ut $\mathrm{i}$ tid.

Den språklige utformingen av asylrapporten er et resultat av samhandling mellom alle personene som er til stede i asylintervjuet. Dermed må tilnærmingen til alle problemstillinger ta hensyn til dette samspillet. Funnene fra pilotprosjektet tyder på at både tolker og intervjuere bør få en grunnleggende innføring i hovedutfordringene med PVT. 


\section{Referanser}

Agrifoglio, M. (2004). Sight Translation and Interpreting. Interpreting, 6:1, 43-67. http://dx.doi.org/10.1075/intp.6.1.05agr

Angelleli Claudia (1999) The Role of Reading in Sight Translation: Implications for Teaching. Volume ATA Chronicle (Translation Journal of the American Association of Translators) XXVIII, No.5, 27-30.

Bruk av tolk i utlendingssaker, RS 2011-039. UDI.

http://www.udiregelverk.no/no/rettskilder/udi-rundskriv/rs-2011-039/ [Lesedato 25.06.2014]

Bollingmo, G. C., Skilbrei, M.-L., \& Wessel, E. (2014). Troverdighetsvurderinger: Søkerens forklaring som bevis i saker om beskyttelse (asyl) (2014:01). Oslo: FAFO.

Changmin, K. (2001). Sight Translation in its Own Right. (MA), California State University, Monterey Bay.

Chmiel, A., \& Mazur, I. (2013). Eye Tracking Sight Translation Performed by Trainee Interpreters. I C. Way, S. Vandepitte, R. Meylaerts \& M. Bartlomiejczyk (Eds.), Tracks and Treks in Translation Studies: John Benjamins.

Ersozlu, E. (2005). Training of Interpreters: Some Suggestions on Sight Translation Teaching. Translation Journal, 9(4).

Et strukturert intervjumetode. UDI

http://www.udiregelverk.no/no/rettskilder/udi-interne-meldinger/ [Lesedato 25.06.2014]

Gile, D. (2009). Basic Concepts and Models for Interpreter and Translator Training: John Benjamins.

http://dx.doi.org/10.1075/btl.8

Hvordan skrive asylintervjurapporten. UDI

http://www.udiregelverk.no/no/rettskilder/udi- interne-meldinger/ [Lesedato 25.06.2014]

Jiménez Ivars, A. (1999). La traducción a la vista. Un análisis descriptivo. (PhD), Universitat Jaume I, Castellón.

Intervju i søknader om beskyttelse. UDI

http://www.udiregelverk.no/no/rettskilder/udi-interne-meldinger/

[Lesedato 25.06.2014]

Lambert, S. (2004). Shared Attention during Sight Translation, Sight Interpretation and Simultaneous Interpretation. Meta, 49(2), 294-306.

http://dx.doi.org/10.7202/009352ar

Langballe, А., Gamst, K. T., \& Jacobsen, M. (2010). Den vanskelige samtalen. Oslo: Nasjonalt kunnskapssenter om vold og traumatisk stress.

Lee, J. (2012). What Skills Do Student Interpreters Need to Learn in Sight Translation Training? Meta, 57(3), 694-714.

http://dx.doi.org/10.7202/1017087ar

Nilsen, Anne Birgitta og May-Britt Monsrud. (forthcoming) Reading Skills for Sight Translation in Public-Sector Services.

Rachlew, A. (2011). Politiavhøret - en beretning fra innsiden. I G. Kvalheim (Ed.), Hjelpe meg! En bok om voldtekt. (pp. 61-73). Stavanger: Hertervig. 
Sampaio, G. R. L. (2007). Mastering Sight Translation Skills.

www.sare.anhanguera/index.php/rtcom/aricle/vieeArticle/135

[Lesedato 25.06.2014]

Shreve, G. M., Lacruz, I., \& Angelone, E. (2011). Sight Translation and Speech Disfluency. In C. Alvstad, A. Hild \& E. Tiselius (Eds.), Methods and Strategies of Process Research: John Benjamins.

http://dx.doi.org/10.1075/btl.94.09shr

Sight Translation and Written Translation, Guidelines for Healthcare Interpreters. National Council on Interpreting in Health Care.

http://www.ncihc.org/assets/documents/publications/Translation_Guidelines_for_Interpreters_.pdf [Lesedato 25.06.2014]

Stansfield, C. (2008). A Practical Guide to Sight Translation of Assessments.

http://txcc.sedl.org/resources/ell materials/summit_march09/stansfield translation_draft.pdf

[Lesedato 25.06.2014]

Wadensjö, C. (1998). Interpreting As Interaction. London and New York: Longman.

Weber, W. K. (1990). The Importance of Sight Translation in an Interpreter Training Program. I D. Bowen \& M. Bowen (Eds.), Interpreting - Yesterday, Today and Tomorrow (pp. 44-52). New York: Binghamton. 